Int. J. Electrochem. Sci., 13 (2018) 3958 - 3969

\title{
Surface Modification of Aluminum Alloy 6061 for Bipolar Plate Application: Adhesion Characteristics and Corrosion Resistance
}

\author{
A. G. González Gutiérrez ${ }^{1}$, P.J. Sebastian ${ }^{1, *}$, L. Magallón Cacho ${ }^{1}$, E. Borja Arco ${ }^{2}$, \\ J. Campos ${ }^{1}$, Agustin Baron ${ }^{1}$ \\ ${ }^{1}$ Instituto de Energías Renovables-UNAM, 62580, Temixco, Morelos. México \\ ${ }^{2}$ Facultad de Química-UNAM, Av Universidad 3000, 04510, C.U. Ciudad de México, Mexico \\ *E-mail: sjp@ier.unam.mx
}

doi: $10.20964 / 2018.04 .122$

Received: 2 April 2017 / Accepted: 30 August 2017 / Published: 6 March 2018

\begin{abstract}
Surface modification studies on aluminum alloy 6061 (AA6061) to improve the surface properties of metallic bipolar plates in fuel cells are presented in this work. The surface of AA6061 was treated first by the electroless process to get a Ni-P coating (AA6061/Ni-P), after that a gold layer was coated by PVD on the modified surface (AA6061/Ni-P/Au). The chemical composition and the roughness variation of the surface during the electroless process were determined by energy-dispersive spectroscopy analysis (EDS) and profilometry respectively. According to XRD studies a solid solution between aluminum and Ni-P interface was formed, improving the adherence of Au on the surface. The corrosion studies of bipolar metal plates were carried out with a potentiostat/galvanostat (Solartron 1287) and a PC with CorreWare software, observing a better corrosion resistance value for AA6061/Ni-P/Au $\left(5.21 \mu \mathrm{A} \mathrm{cm}^{-2}\right)$ compared to bare AA6061 $\left(51 \mu \mathrm{A} \mathrm{cm}^{-2}\right)$. The open circuit potential was measured during 4 hours simulating the anodic and cathodic environments and the best performance was observed for AA6061/Ni-P/Au for both environments.
\end{abstract}

Keywords: AA6061, bipolar plate, electroless deposition, corrosion resistance, PEMFC.

\section{$\underline{\text { FULL TEXT }}$}

(C) 2018 The Authors. Published by ESG (www.electrochemsci.org). This article is an open access article distributed under the terms and conditions of the Creative Commons Attribution license (http://creativecommons.org/licenses/by/4.0/). 